\title{
1967-A Year of Constraints on Monetary Management
}

\section{N}

ONETARY ACTIONS in 1967 were very expansionary until the last few weeks of the year. These actions followed a period of very strong monetary restraint during the last half of 1966 . The pace of economic activity slowed during the first half of 1967 and, in response, the Federal Open Market Committee (FOMC) continued the expansionary monetary policy adopted in late 1966. During the second half of 1967 prices resumed their rapid upward advance of late 1966. Nevertheless, FOMC policy was not changed significantly until late in the year; prior to then a majority of the Committee accepted several constraints on its ability to adopt a restrictive monetary policy.

This article is a review and interpretation of the record of the Federal Open Market Committee during 1967. The article is divided into two parts; part one a review of monetary management in 1967 , and part two a detailed discussion of several constraints that influenced the Committee in its monetary policy actions during the second half of the year. The bases for the article are, for the most part, the policy records of the FOMC and its policy directives. In 1967 the FOMC adopted a new procedure for informing the public of its actions. About ninety days after a Committee meeting, a summary of its deliberations is released; these summaries are called the policy record of the FOMC. At the same time, the Committee's current economic policy directive to the New York Federal Reserve Bank is released. Both of these documents are readily available to the public in the Federal Reserve Bulletin. A summary of these directives for 1967 is presented below in Exhibit 1, while some of the factors which influenced the formulation of the directives are presented in Exhibit 2.

\section{PART ONE}

\section{MONETARY MANAGEMENT IN 1967}

The procedures used by the FOMC for monetary management during 1967 were little changed from long-established traditions. ${ }^{1}$ At each meeting, the Committee issued a current economic policy directive which usually consisted of two paragraphs. The first paragraph contained a statement of economic goals sought by the Committee, along with a summary of important economic developments. The second paragraph contained general operating instructions to the Federal Reserve Bank of New York for the implementation of the Committee's monetary policy until the time of its next meeting. The Manager of the Federal Reserve System's open market account has the day-to-day responsibility for carrying out these operating instructions.

As has been the practice for many years, the Committee's operating instructions during 1967 were framed primarily in terms of money market conditions. In arriving at a directive, members of the FOMC

\footnotetext{
For a detailed discussion of these procedures, see the following articles in the Federal Reserve Bank of St. Louis Review: "1966-A Year of Challenge for Monetary Management," April, 1967; "Federal Reserve Open Market Operations in 1965: Objectives, Actions and Accomplishments," June, 1966; and "Implementation of Federal Reserve Open Market Policy in 1964," June, 1965.
} 


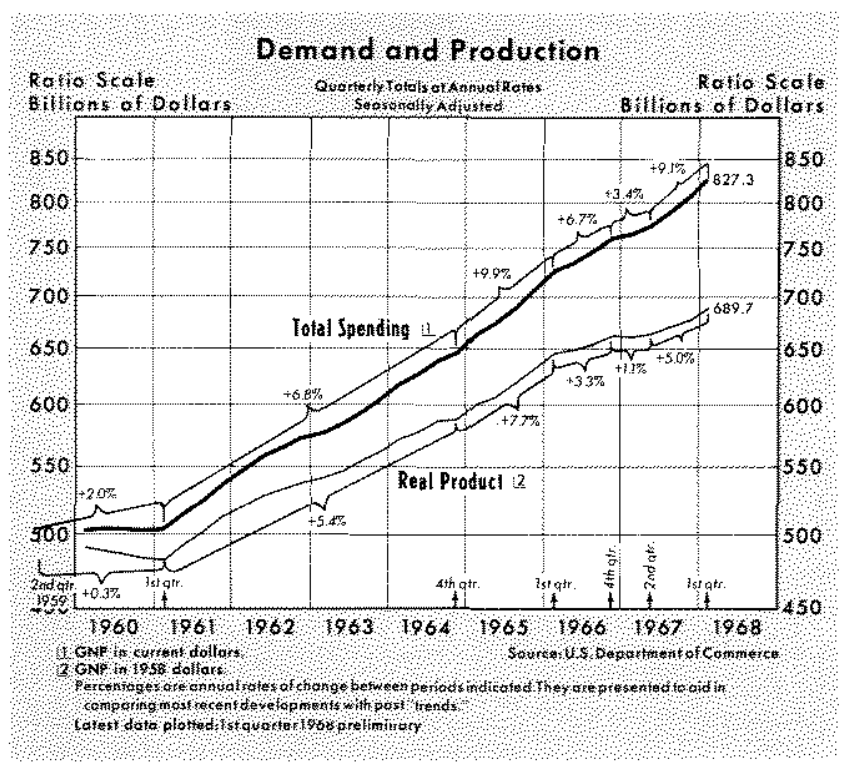

have taken into consideration many measures of market conditions. One measure is the difference between member bank excess reserves and borrowings from Reserve banks, a positive difference being called free reserves and a negative difference net borrowed reserves. Various short-term interest rates, such as the Federal funds rate, the Treasury bill rate, and lending rates charged on loans to Government securities dealers by large money market banks, also are used as measures of money market conditions; an increase in short-term interest rates is taken to indicate "tighter" money market conditions, and a decline to indicate "easier" conditions.

Most FOMC directives for last year continued the practice, started in 1966, of having a proviso clause included in the directive to the Federal Reserve Bank of New York. The proviso clause instructs the manager to alter money market conditions in the event that a monetary aggregate does not move in a prescribed manner; the aggregate measure used most frequently last year was bank credit. Since both Federal Reserve actions and economic activity affect measures of money market conditions, the proviso clause assists in gauging the impact of System's monetary management efforts on money market conditions.

An examination of the policy record and directives adopted by the FOMC during 1967 indicates that the year might be usefully divided into four periods. From January through April the FOMC moved toward monetary ease in response to slower growth in economic activity. A revival of economic expansion seemingly was apparent by early summer; therefore, from May through July there was cautious optimism about the state of the economy, and policy remained easy. From August through mid-November inflationary pressures emerged once again, but policy remained largely unchanged. After December the FOMC moved toward moderate restraint.

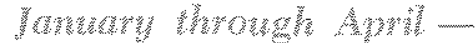

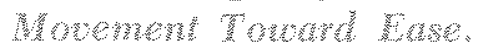

The first four months of 1967 may be characterized as a period of slackened economic activity and some fear of recession. Growth in total demand and real output slowed while industrial production and em. ployment declined. Federal tax policy remained uncertain, and the nation's balance of payments problem persisted.

There was general agreement among Committee members that economic developments during the period called for policy designed first to promote noninflationary economic expansion and then to counteract weakening tendencies in the economy. To achieve these objectives the System employed its three general tools of control: open market operations, discount rate policy, and adjustment of member bank reserve requirements.

Early in 1967 the Committee was following policy designed to "foster money and credit conditions conducive to noninflationary economic expansion and progress towards reasonable equilibrium in the country's balance of payments." To achieve these broad policy goals, the New York Reserve Bank trading desk had been instructed in the final directive of 1966 that open market operations were to be conducted in a manner designed "to achieve somewhat easier conditions in the money market, unless bank credit

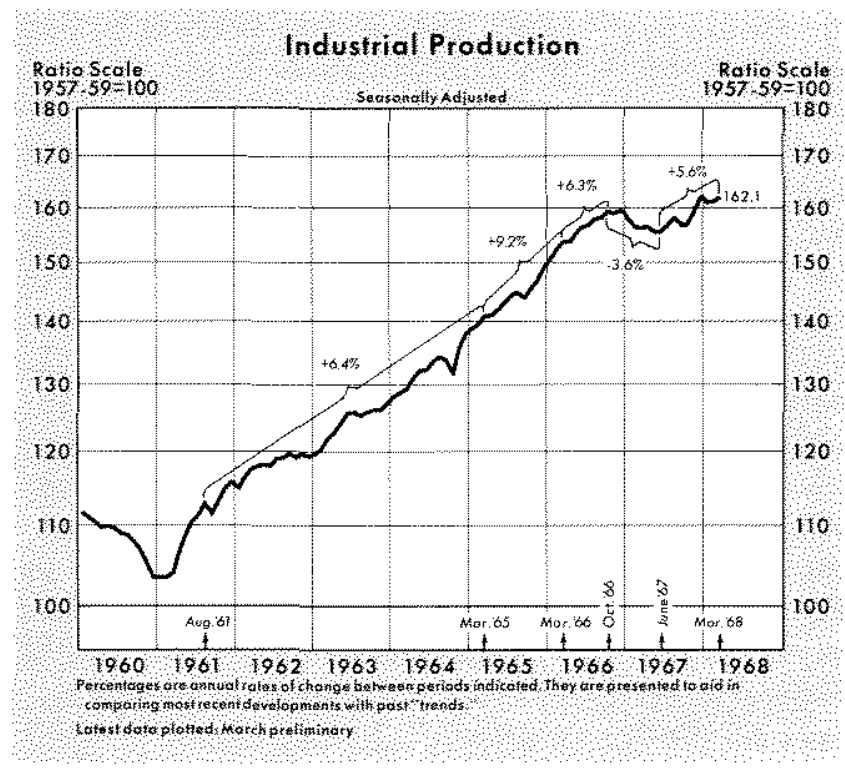




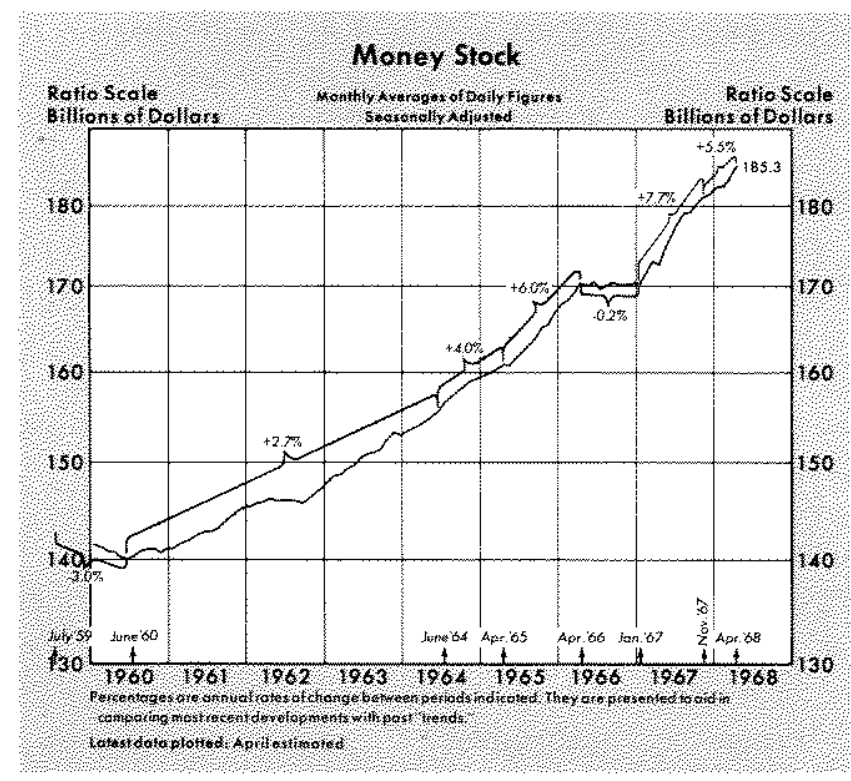

appears to be resuming a rapid rate of expansion."

At the first meeting of 1967 (January 10) the Committee noted that, although GNP rose sharply in the fourth quarter of 1966 as the rate of inventory accumulation increased sharply, growth had slackened in consumer spending for goods, business capital outlays, and in Federal defense expenditures. Furthermore, housing was still relatively weak and industrial production was little changed from August. Staff projections suggested a marked slowing in the growth of GNP and industrial production during the first quarter of 1967, and a moderate increase in the unemployment rate.

The majority of the Committee felt that some further easing of money market conditions was appropriate. Others expressed concern, however, about the effects of any move toward further monetary ease on the grounds that the balance of payments remained a serious problem and that, although some economic indicators were showing softness, the longer run prospects for the economy were strong. Under these circumstances, the manager was instructed to attain somewhat easier market conditions (Exhibit 1). The proviso clause was changed to read that operations should be modified if "bank credit appears to be expanding significantly faster than currently anticipated."

2Dissenters to this action included: President Irons of the Dallas Reserve Bank; Governor Shepardson of the Board of Governors; and First Vice President Treiber of the New York Reserve Bank. Among the considerations ad. vanced were the continuing balance of payments problem and the desirability of awaiting further information on prospective Federal taxes and expenditures before changing monetary policy further.
At the meeting on February 7 the operating policy instructions stated that open market operations should be conducted with a view "to maintaining the prevailing conditions of ease in the money market." It was further added that operations should be modified as necessary "to moderate any apparently significant deviations of bank credit from current expectations." The inclusion of a two-way proviso clause empowered the manager to alter open market operations to provide further ease should bank credit grow more slowly than expected, or to tighten if bank credit rose more rapidly than anticipated. The Board of Governors announced on February 28 a reduction in reserve requirements for member bank savings deposits and certain time deposits for the purpose of meeting developing credit needs throughout the country.

At the March 7 meeting the Committee voted in favor of a policy "to foster money and credit conditions, including bank credit growth, conducive to combating the effects of weakening tendencies in the economy ..." To implement this policy, open market operations until the next meeting were to "be conducted with a view to attaining somewhat easier conditions in the money market, and to attaining still easier conditions if bank credit appears to be expanding significantly less than currently anticipated."

Information reviewed at this meeting suggested that the apparent pause in economic activity recognized in previous meetings was indeed real, and the Committee agreed that actions should be geared to fighting weakening tendencies in the economy. This feeling carried over to the April 4 meeting when the Committee agreed to maintain substantially the existing set of policy goals and directive. Shortly thereafter, in order to align the discount rate with most short-term market rates of interest and to assure an adequate availability of credit to provide for orderly economic growth, the Reserve Banks reduced the rate charged on discounts to member banks from 4.5 per cent to 4 per cent.

Reflecting System reserve supplying operations, money market conditions eased markedly from January through April. Net reserve availability, as measured by "free" reserves, rose from a minus (net

3Covemor Mitchell dissented from this action because he favored moving somewhat further toward ease. He was "inclined to give more credence to the present expectam tions for a weaker economic performance in the first half of the year than to those for a stronger performance in the second half ..." 
borrowed) $\$ 100$ million early in the year to a range of around $\$ 275$ million by early May. Member bank borrowing from Reserve Banks declined from an average of about $\$ 560$ million per week in December 1966 to around $\$ 100$ million in early May. The Federal funds rate, which had averaged about 5.3 per cent as the year opened, fell to around 4.5 per cent by late March and to 4 per cent in early May. The smaller spread between the Federal funds rate and the discount rate probably contributed to the decline in member bank borrowing from the System during the first four months of 1967 .

Long-term and short-term interest rates moved in divergent patterns from the end of January through April. Short-term rates declined generally about a percentage point, while a large volume of capital market floatations by corporations and state and local governments put upward pressure on long-term rates. The 91-day Treasury bill rate closed the period at about 3.75 per cent, compared with 4.72 per cent in January; while the yield on long-term Government bonds reached about 4.60 per cent, compared with 4.40 per cent in January.

Coincident to the easing in the money market, aggregate monetary indicators expanded rapidly. Member bank reserves rose at a 12 per cent annual rate from January through April, the money stock at a 6 per cent rate, and money plus time deposits at a 12 per cent rate. Bank credit rose at a rapid 15 per cent annual rate, while the monetary base (total member bank reserves adjusted for reserve require-

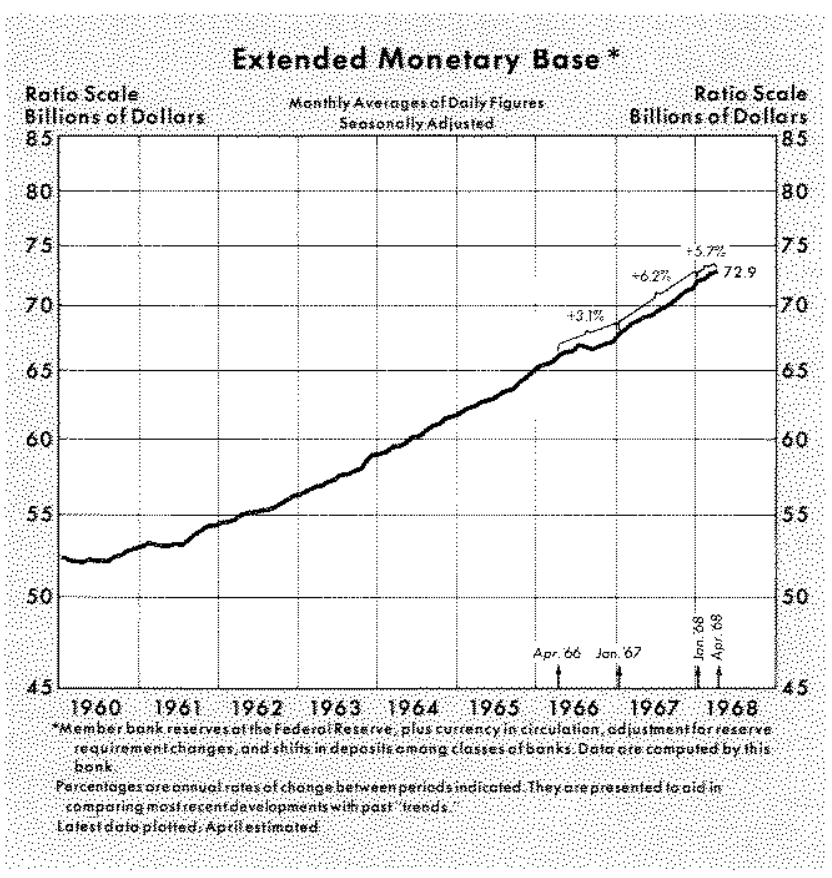

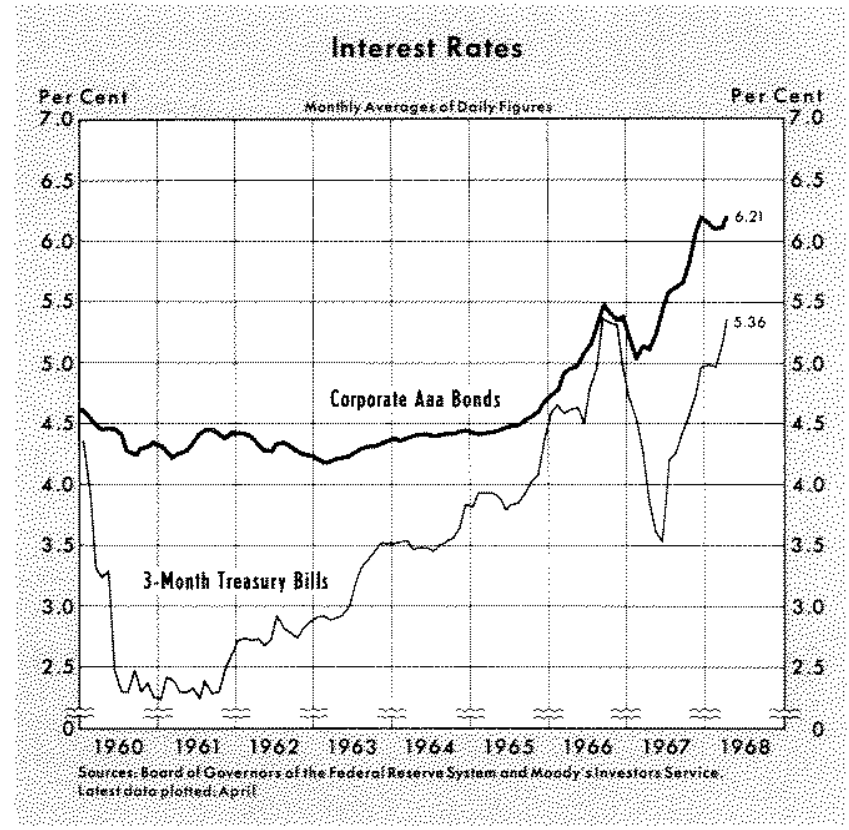

ment changes plus currency in the hands of the public) rose at a 6.8 per cent rate. ${ }^{*}$ All of these rates were generally well above their respective trend rates of the early 1960 's.

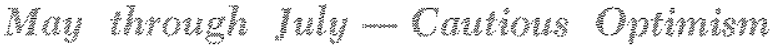

Beginning in early May, the Committee's policy shifted from seeking progressively easier conditions in the money market to maintaining prevailing conditions; the prospects for renewed economic expansion had improved. However, in the process of maintaining an existing constellation of money market rates during a period when the demand for credit was particularly intense, aggregate monetary measures - reserves, money, bank credit-expanded at rapid rates.

At the FOMC meeting on May 2 it was generally recognized that factors which had contributed to the pause in economic activity during the early months of the year were fading. The adjustment to excessive inventories was being facilitated by reduced indus-

\footnotetext{
4The monetary base consists of the net of several items on the Federal Reserve's balance sheet. The base is calculated by summing: member bank borrowings from the Federal Reserve, other Federal Reserve credit, and the gold stock; less the sum of: Treasury currency outstanding, Treasury deposits at the Federal Reserve Treasury cash holdings, and other deposits plus other Federal Reserve accounts. The base has been adjusted for reserve requirement changes and shifts in deposits among classes of banks and types of deposits. This measure provides a useful indicator of monetary policy because it is not affected by random movements of funds between private deposits and Government accounts at commercial banks.
} 


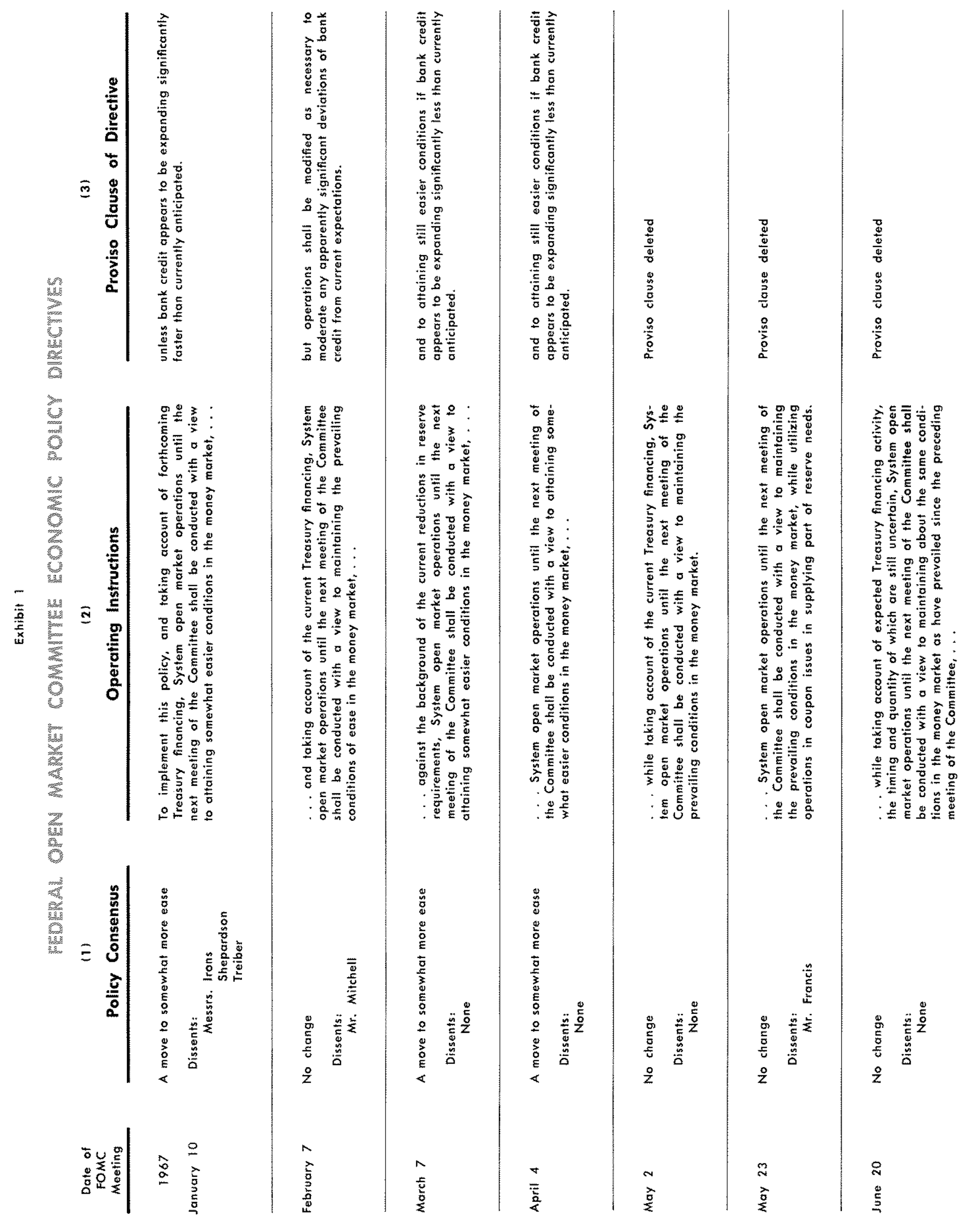




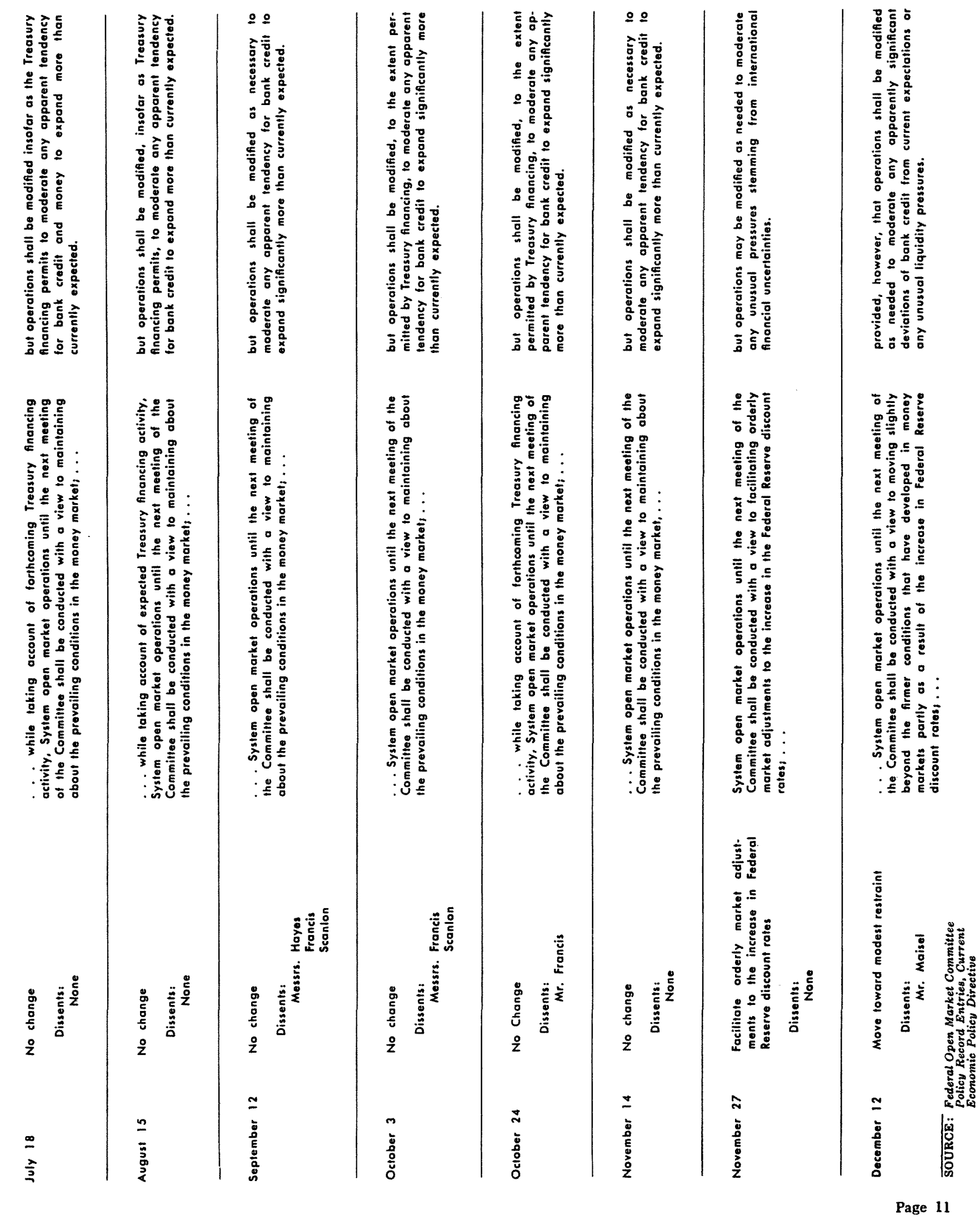


trial output and strengthened consumer purchasing. Real GNP was projected to rise slightly in the second quarter and sharply in the third.

In this situation, the Committee voted for policy to foster money and credit conditions "conducive to renewed economic expansion." For the first time in 1967, the proviso clause was deleted. The broad policy directive was not altered substantially at the following three meetings: May 23,5 June 20, or July 18, although the proviso clause was reintroduced at the July meeting.

Money market conditions from May through July generally remained easy. Federal funds traded around the discount rate, more often below it than above. Free reserves averaged around $\$ 280$ million, about the same figure that prevailed at the close of the previous period. Excess reserves remained relatively unchanged, while borrowing from Reserve Banks stayed near $\$ 100$ million.

Reflecting in part the rapid rate of monetary expansion earlier in 1967 and the unprecedented demands for funds by corporations, interest rates in the capital market moved sharply higher. In early summer the 91-day Treasury bill rate reversed its earlier downward trend and rose about half a percentage point from April through July. Yields on longterm Government bonds and prime corporate securities in late July were about 5 per cent and 5.6 per cent, respectively, somewhat above the highs of late 1966.

In attempting to maintain existing money market conditions in the face of strong demands for credit, Federal Reserve actions provided sizable amounts of credit to the banking system. From May through July Federal Reserve credit rose at a rapid 9 per cent annual rate, with most of the impetus provided by System acquisitions of Government securities, including coupon issues. Other aggregate measures also expanded rapidly. Bank reserves rose at a 10 per cent rate, money at a 12 per cent rate, money plus time deposits at a 15 per cent rate, and total bank credit at a 12 per cent rate. Finally, the monetary base rose at a 4.4 per cent annual rate during the period. All these rates of growth were quite high by historical standards.

\footnotetext{
5President Francis of the St. Louis Reserve Bank dissented to this action on the grounds that a marked increase in demands for goods and services was likely later in the year and that monetary policy actions had their main effects after some time lag. He thought some firming in the money market should be sought now to guard against the development later of excessive demand and associated inflationary pressures.
}

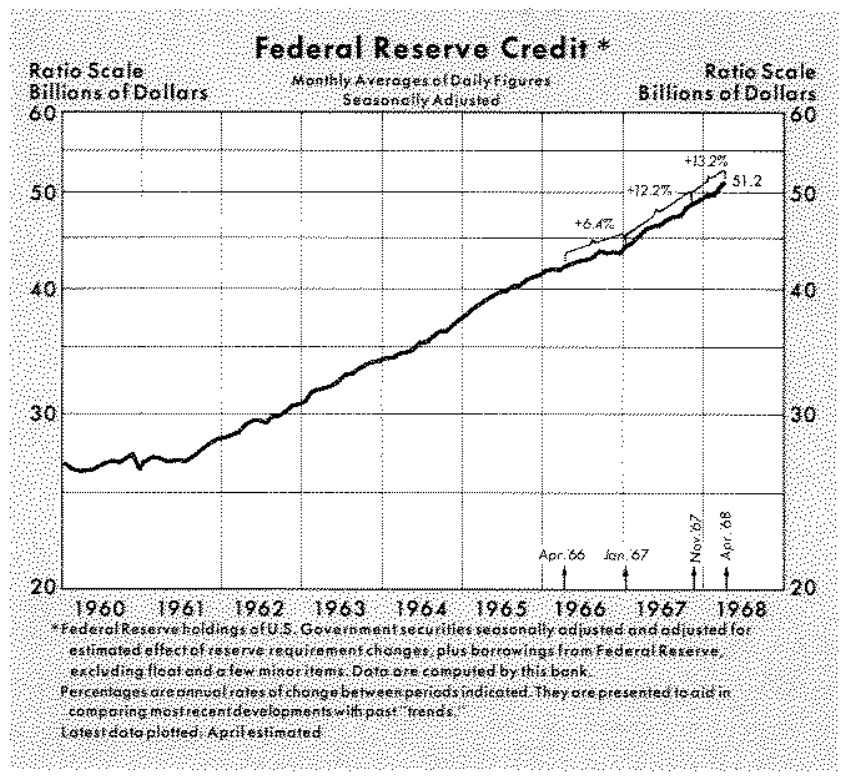

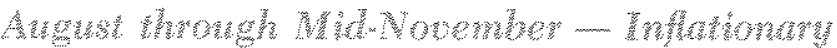

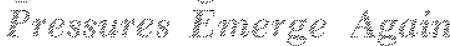

Underlying economic conditions strengthened during the fall, despite the adverse effects of strikes in the automobile industry and elsewhere. Real GNP, final sales, and employment rose sharply. At the same time, however, inflationary pressures began to emerge and the general price level rose rapidly.

Interest rates rose, reflecting in part the impact of previous expansionary monetary policy and the accelerated supply of corporate and U.S. Government securities. Inflationary expectations induced borrowers to pay, and lenders to demand, higher rates for funds. The underlying balance of payments position deteriorated, and there was concern over the condition of the British overseas payments position.

There was a general feeling among the FOMC during this period that inflationary pressures, the rapid rate of bank credit growth, and the balance of payments problem all warranted a move toward monetary restraint. However, the constraints of "even keel," financial "disintermediation," the proposed tax legislation, and the position of sterling in the foreign exchange markets militated against any move toward restraint. Monetary policy was conducted with a view to maintaining prevailing conditions in the money market.

The Committee voted at the August 15 meeting to maintain substantially the same set of policy goals adopted at the previous meeting. Most members thought that recent rates of growth in bank credit were higher than should be sustained in light of the existing economic outlook. However, the feeling 


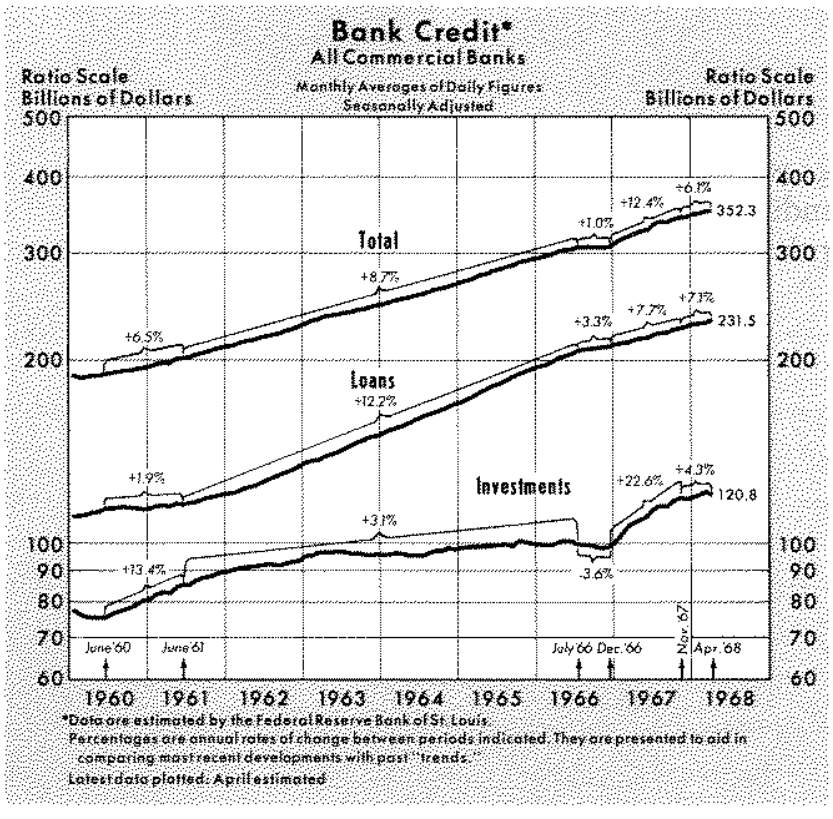

was expressed that the upcoming Treasury financing, together with uncertainty concerning the fiscal program then being discussed in Congress, precluded any move toward monetary restraint at that time.

At the following meeting (September 12) the Committee voted to maintain prevailing conditions in the money market, and to promote "sustainable" rather than "continuing" economic expansion," The majority supported the decision to avoid a movement toward restraint while awaiting clarification with respect to likely Congressional action on the President's tax pack. age. Moreover, it was again argued that even a modest move toward restraint might cause a further rise in market interest rates, with possible adverse effects on depository type financial intermediaries and on the position of the pound sterling in the foreign exchange markets.

\footnotetext{
Members who dissented from this action included: President Hayes of the New York Reserve Bank President Francis of the St. Louis Reserve Bank; and President Scanlon of the Chicago Reserve Bank. Mr. Hayes and Mr. Scanlon felt that "greater monetary restraint was required in bank credit, required in light of recent rates of growth in bank credit, present and prospective inflationary pressures, and the unsatisfactory balance of payments situation." Mr. Francis favored seeking "significantly firmer money market conditions and firming still further if growth in bank credit did not moderate substantialy. He judged that "both monetary policy and fiscal policy were characterized by excessive ease at present, the lagged effects of which would magnify the pressures on the economy expected in the months ahead." $\mathrm{Mr}$. Francis observed that "fiscal policy was likely to rernain extraordinarily stimulative even if the President's tax proposals were enacted in the form recommended." He expressed the view that "the limitation by appropriate monetary action of excessive demand, inflation, speculation, and further detertoration in the U.S. balance of payments appeared to be more crucial than any temporary hardships on the Treasury, financial intemediaries, and long-term borrowers resulting from higher interest rates."
}

The policy goals were not altered significantly at the two meetings during October ${ }^{7}$ and the one on November 14, although some Committee members felt that underlying economic conditions called for a movement toward a firmer policy stance. The majority again felt that these factors were outweighed by other factors, including the continued need to await clearer indications of Congressional action with regard to Federal taxes and expenditures, uncertainties with respect to the extent and duration of the auto industry strike, and the fear that firmer policy might lead to sharply higher interest rates with undesired domestic and international economic impacts. Impending Treasury financings and the position of the pound sterling were also mentioned as factors militating against a policy change.

Conditions in the money market remained quite easy during the late summer and fall of last year, as the Federal Reserve provided reserves rapidly to the banking system through open market operations. Federal funds traded at or near the discount rate, and member bank borrowings at the discount window remained at an average of about $\$ 100$ million. Net

Those who dissented from the action taken on October 3 included President Francis and President Scarlon. In their judgment, "in view of the prospects for further price inllation the risks in not acting at this time to moderate the rapid growth of bank credit outweighed the various considerations seen as militating against a firmer monetary policy." President Francis dissented from the action taken on October 24, and stated that he favored "seeking whatever degree of firming in the money market conditions would be required to moderate substantially the growth in bank, credit and the money supply by the end of the year." He felt that "the national interest called for greater monetary restraint now to curb inflationary pressures and to protect the foreign trade component of the U.S. balance of payments."

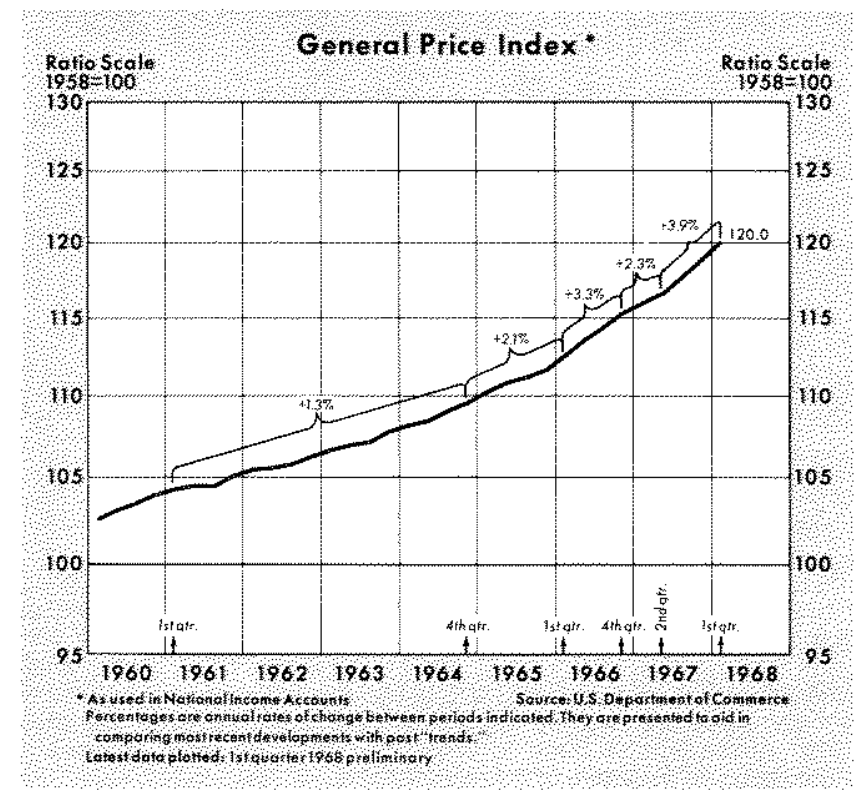


reserve availability, reflected by the level of free reserves, averaged about $\$ 250$ million, very much in line with what the Committee had expected.

Developments in the capital market continued to be dominated by the unprecedented demands for funds, as borrowers accelerated security offerings. By the end of October the 91-day Treasury bill rate was about 4.6 per cent, while rates on long-term Government bonds and high-grade corporate securities reached about 5.3 per cent and 6 per cent, respectively. These rates were in sharp contrast to the bill rate of 3.6 per cent, Government bond rate of 4.9 per cent, and high-grade corporate yield of 5.4 per cent which had prevailed in mid-June.

Aggregate monetary measures rose quite rapidly during the late summer and fall. Reserves rose at an 11 per cent rate, the money stock at a 5 per cent rate, and money plus time deposits at a 9 per cent rate. Bank credit rose at a 9 per cent anmual rate, despite the fact that interest rates were rising. Finally, the monetary base rose at about a 7 per cent rate.

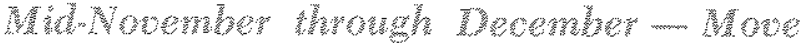

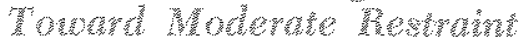

Following the British devaluation of the pound sterling on November 18 , monetary policy moved toward moderate restraint. To implement a more restrictive policy, the Federal Reserve employed a discount rate increase, announced adjustments in re serve requirements, and, to an extent, open market operations. In the process of accommodating yearend demands for credit, policy action resulted in a rapid increase in most monetary aggregates. The acceleration proved temporary, however, and the growth in most monetary aggregates abated in early 1968.

In the wake of the sterling devaluation and the increase in the British bank rate to 8 per cent, the Federal Reserve discount rate was raised from 4 to 4.5 per cent, in part to moderate an expected outflow of short-term capital from the United States. At a meeting of the Committee on November 27, it was noted that "various cross currents were likely to be at work be cause of the increase in the discount rate and of recent events abroad, and because of the uncertain impact of these events on domestic financial markets." A current economic policy directive was issued instructing the Desk to conduct open market operations until the next meeting with a view toward "facilitating orderly market adjustments to the increase in Federal Reserve discount rates." But operations were to "be modified as needed to moderate any unusual pressures stemming from international financial uncertainties."

At the final meeting of 1967 it was noted that the business outlook for early 1968 appeared strong. Consumer spending was expected to rise. Plant and equipment expenditures were expected to rise considerably during the first half of 1968 , and outlays for residential construction appeared likely to continue upward. The fourth quarter balance of payments on liquidity basis had deteriorated sharply, partly reflecting the rapid rise in domestic prices. The international payments problem was intensified by heavy speculation against the dollar in the London gold market following the sterling devaluation. This speculation had led to a sizable decline in the U.S. Treasury gold stock.

The Committee concluded at the December 12 meeting that events of the recent weeks had shifted the balance of considerations in favor of a firming of monetary policy. It was decided that open market operations until the next meeting should be conducted with a view to moving "slightly beyond the firmer conditions that have developed in money markets partly as a result of the increase in Federal Reserve discount rates . . " 8 The Board of Governors, on December 27, announced a selective increase of reserves required as backing for commercial bank demand deposits.

The money market showed indications of firmness from mid-November through December. Free reserves ranged around $\$ 150$ million, down about $\$ 50$ million from the level of early November. The Federal funds rate moved higher, and funds generally traded above the 4.5 per cent discount rate after midDecember. During this period, the three-month Treasury bill rate moved sharply higher to about 5 per cent by year-end.

From November 1967 thru April 1968, growth in monetary aggregates slowed relative to the rates during the first eleven months of last year. Bank reserves rose at an estimated 4.2 per cent annual rate, money at an estimated 5.5 per cent rate, and money plus time deposits at an estimated 5.8 per cent rate. The monetary base increased at a 5.7 per cent rate from January 1968 through April.

\footnotetext{
sovernor Maisel dissented from this action "in part be cause he thought the directive was susceptible to an interpretation under which growth in member bank re serves and bank deposits would be slowed too abruptly, and perhaps succeeded by contraction." He favored "sceking growth rates in reserves, deposits, and bank credit considerably below the average rates thus far in 1967, but still high enotigh to facilitate expansion in GNP at a somewhat faster rate than had prevailed on average in the first three quaters of the year.
} 


\section{PART II}

\section{CONSTRAINTS ON MONETARY MANAGEMENT LAST HALF 1967}

Monetary management operates within the context of national economic stabilization policy, which includes fiscal actions of the Federal Government. This policy has three general goals: rising output, a high level of employment, and relatively stable prices. In addition, stabilization actions are often used to achieve a viable position in the nation's international balance of payments. The tools most frequently used for achieving these goals are fiscal actions and monetary management. Fiscal actions refer to the taxing and spending programs adopted by the Federal government. Monetary management refers to actions of the Federal Reserve System designed to achieve national economic goals. These actions involve changes in monetary aggregates such as member bank reserves, the monetary base, the money stock, and commercial bank credit, along with changes in market interest rates.

During last year an impasse was reached in the adoption of fiscal restraint, and several constraints prem vented the adoption of restrictive monetary actions until late in the year. The balance of this article is devoted to an examination of these constraints on monetary management. There is little literature available on these constraints, and the FOMC has given very little public information justifying their imposition. Therefore, the views and interpretations presented here are those of the authors.

\section{The Constraints}

Despite a general recognition in the fall of 1967 that monetary policy should have become restrictive, the Policy Record of the FOMC indicates that four major considerations constrained the Committee from making a major shift in its policy (Exhibit 2). These considerations were a belief that "even keeling" is necessary during Treaury financings, a fear of causing renewal of disintermediation, a desire to await the outcome of pending tax legislation, and a concern over the position of the British pound sterling.

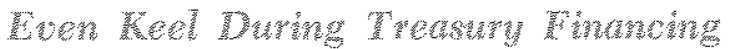

During 1967 "even keel" considerations played an important role in the FOMC directives adopted at eight out of its 14 regularly scheduled meetings. The term "even keel" is a nebulous concept which has played an important role in FOMC discussions during the 1950 's and 1960 's. Basically, it means that from a few days before an announcement of a Treasury financing until a few days after final distribution of the securities, Federal Reserve actions by themselves should cause neither a decrease nor an increase in the price of Government securities. Presumably, other market forces would be allowed to change market prices of securities. Even keel, therefore, precludes any changes in monetary policy during major Treasury financings, although market interest rates may fluctuate in response to other market forces.

An even keel policy has been justified on grounds that Government security dealers and other underwriters of new Treasury securities should be able to enter a bid for a new Treasury issue and to retail the issue to ultimate buyers at the offered price plus a normal mark-up. If, as a result of Federal Reserve actions, they should receive a price less than the acquisition price plus normal mark-up, dealers would have a capital loss and would be discouraged from bidding on future issues. On the other hand, if they should receive a price higher than their acquisition cost plus normal mark-up, dealers would have received an unnecessary capital gain. A policy of even keel evidently is based on a concern over the viability of the Government securities market and the success of Treasury financings.

A period of even keel usually extends for many days. Generally, the FOMC has felt constrained from changing its policy from the formal announcement of a Treasury financing to a date when most of the new issue has been distributed to ultimate holders. Hence, this constraint may be operative for most of the time between two meetings of the FOMC.

There seems to be a scale regarding the importance of even keel according to the types of securities involved in a financing and the amount of net new money being raised by the Treasury. Even keel is never invoked during a Treasury bill financing in

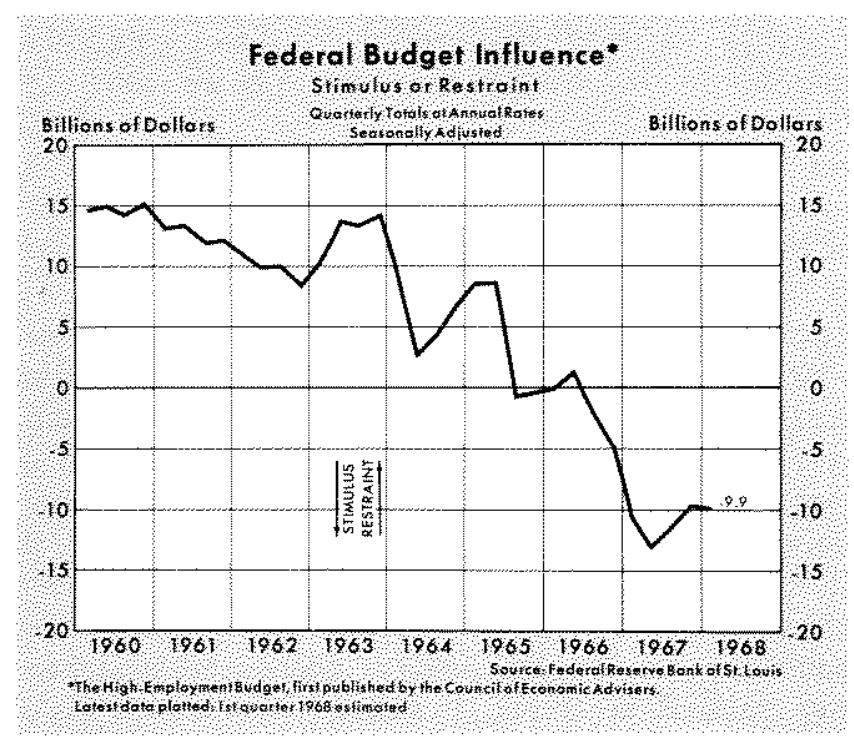


Date of

FOMC

Meeling

1967

January 10
(1)

Even Keel
(2)

\section{Financial Disintermediation}

The Committee agreed that the forthcoming Treasury financing should be taken into account in the conduct of open-market operations...

February 7 The current Treasury financing also was mentioned las a factor militating against a further deliberate relaxation of monetary policy at present) ...

. Efforts should be made to resist any sharp rises in interest rates but that rates should be permitted to decline if market forces worked in that direction.

\section{March 7}

No constraints cited

April 4

No constraints cited

May 2 . . The desirability of maintaining on "even keel" in the money market during the current Treasury financing (was) advanced as grounds for such a policy course.

May 23

June 20

July 18

August 15

September 12
.. . it would be appropriate at that time to maintain about the same conditions in the money markel as had prevailed since the preceding meeting, partly because of the expected Treasury financing.

If was generally agreed that the Treasury's fortheoming financing militated against seeking a change in money market conditions at present.
. . a number (of members) expressed concern about the continued uptrend in long-term interest rates, particularly in light of the risk that higher rates might slow the recovery in the housing industry and in the economy generally.

. The possibility that any significant further increases in market interest rates might reduce the flow of funds into mortgages and slow the recovery underway in residential construction activity.

... impending Treasury financing . . militated against a change in monetary policy of present.

- the risks that under present conditions in financia markets even a modest move loward greater monetary restraint at this time might have an exaggerated impact on market expectations and result in sharp further increases in interest rates, with attendant adverse effects on depositary type financial intermediaries...

October 3 The Treasury's current bill financing and, more importanlly, the November refunding soon to follow also were cited os considerations arguing against a change in monetary policy at this juncture.

October $24 \quad$.. the forthcoming Treasury financing precluded any change in monetary policy at this time.
. the risk that under present financial market conditions any firming action at this lime would lead to sharply higher interest rates, with possible undesired effects on financial intermediaries...

In addition, it was noted that further increases in market interest rates at this time might well have undesired effects on flows of funds to financial intermediaries...

November 14

November 27

December 12 . . the constraint imposed from time to time by Treasury financing acfivity was absent for the time being.

SOURCE : Federal Open Market Committee Policy Record Entries.
. . the decision to move toward only slightly firmer condilions - and to provide for modifications of operations in the event that unusual liquidity pressure developed - reflected in part continuing concern about the possible adverse effects of higher interest rates on financial intermediaries...

Page 16 
-. it was noted that appropriate monetary policy over coming months would depend importantly on the nature of Federal fiscal policies.

. . The prospect, which some members thought has been enhanced recently, that action to raise Federal income taxes might be taken soon.

. . some members also referred in this connection to the growing expectation that the Administration would press for measures of fiscal restraint.
The current (economic) situation was characterized by various cross-currents and uncertainties.

. . The absence to date of firm evidence that the widely expected upsurge in economic activity had already begun.

. . uncertainties about the outcome with respect to the fiscal program now under active consideration by Congress militated against a change in monetary policy at present.

Members of the majority advanced various reasons in support of this course, including the desirability of waiting for firmer indications of the likely nature of action by Congress with regard to the President's tax proposals.
. greater monetary restraint af this time might hove an exaggerated impact on market expectations and result in sharp further increases in interest rates, with attendant adverse effects on . . The position of sterling in the foreign exchange markets. ...existing uncertainties with respect to the extent, duration, and ultimate economic effects of the strike in the automobile industry.
. . the desirability of awaiting firmer indications of the probable actions by Congress with respect to Federal taxes and expenditures...

the continuing uncertainties regarding the probable outcome of the current congressional debate on fiscal policy measures.
.. any firming action at this time would lead to sharply higher interest rates... With possible undesired effects... On the position of sterling in foreign exchange markels.

.. further increases in market interest rates of this time might well have undesired effects... On the position of sterling in foreign exchange markets.
. . the Committee agreed that no change should be made in monetary policy at this lime, in view of the sensitive state of conditions in foreign exchange markets and of the international negotiations now underway.
Eftorts to achieve a measure of fiscal restraint through -nactment of a surcharge on income taxes had proved unavailing in the 1967 session of Congress.
The constraint on monetary policy resulting from the pressures on sterling in foreign exchange markets had been relaxed, although not completely removed, by the devaluation of the pound;...
... the uncertainties regarding the extent and duration of the automobile industry strike.

The Committee took note... of the continuing uncertainties with respect to international developments and their possible impact on domestic financial markets. 
volving merely a roll-over of maturing securities into new issues. Even keel may be invoked when a sizable amount of new cash is involved, such as in an offering of tax anticipation bills. Whenever a coupon issue is involved, the even keel constraint virtually always is invoked.

In the second half of 1967 the even keel constraint was cited in four FOMC directives: July 18, August 15, October 3, and October 24. At the December 12 meeting it was cited as being, at that time, absent as a constraining factor. In the first two cases the proviso clause read, ". . . but operations shall be modified insofar as the Treasury financing permits to moderate any apparent tendency for bank credit and money to expand more than eurrently expected." In the October directives the proviso clause read, ". . . but operations shall be modified, to the extent permitted by Treasury financing, to moderate any apparent tendency for bank credit to expand significantly more than currently expected."

Bank credit, as noted previously, continued to rise rapidly throughout the last half of 1967 until late in the period. At most of the FOMC meetings the Committee staff's near term projections were for rapid bank credit expansion. One interpretation of this continued expansion in bank credit suggests that bank credit was allowed to expand in line with these projections so there was no need to invoke the proviso clause. Another interpretation would be that even keel considerations during the Treasury financings were viewed as not permitting any change in the rate of bank credit expansion because actions to reduce the rate of expansion would have resulted in higher interest rates, with possible undesired economic effects.

\section{Concen ONer Penewed Dismemedinton}

Market interest rates rose markedly in the fall of last year, and concern was expressed by a majority of the FOMC that deposit type financial intermediaries again could be in the same undesirable position they were during the period of monetary restraint in 1966. Regulatory agencies have imposed ceilings on interest rates paid on commercial bank time and savings deposits, mutual savings bank deposits, and savings and loan association share accounts. In the last half of 1966 market interest rates exceeded by a substantial margin these ceiling rates. As a result, these financial intermediaries lost funds to the money and debt markets, and the construction industry, which is a major outlet for funds acquired by these intermediaries, was severely depressed.

The Policy Record of the October meetings of the
FOMC indicate a prevailing concern on the part of a majority that a similar situation for financial intermediaries and the construction industry possibly could develop if a policy of restraint was adopted. Furthermore, even though a policy of restraint was adopted at the December 12 meeting, the proviso clause called for modification in open market operations if there developed ". . . any unusual liquidity pressures." Deposit type financial intermediaries make quarterly or semi-annual interest and dividend payments at the end of a calendar year and are subject to withdrawals of funds by depositors at that time. In the event that funds flowed out of these institutions in great amounts, restraint was to be abated.

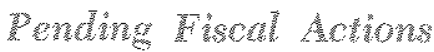

The President's January budget message for the 1968 fiscal year called for a 6 per cent surtax on both personal and corporate incomes. Action on this proposal was not taken by Congress, and in August of last year the President requested a 10 per cent surtax. The FOMC directives of August 15 and September 12 cited this proposal as one "which would make a substantial contribution to balanced economic growth." The October 3 directive said, "The President's new fiscal program is still pending before Congress."

A major argument advanced against a shift toward a tnore restrictive monetary policy early last fall was that a marked change should wait until there was evidence that there would be some measure of fiscal restraint. In addition to restraining inflation, it was argued by various individuals in the Federal Reserve System and in the Administration that a tax raise was needed to avoid higher interest rates. The tax increase would tend to limit the demand for funds by businesses and consumers competing with. Treasury financings of a sizable deficit. Also, greater government revenues would reduce the size of the deficit requiring finaneing. The Committee chose to delay a move toward monetary restraint when there was the possibility of fiscal restraint.

\section{Position of the Brytes pound}

The position of British pound in foreign exchange markets, according to FOMC records, was of continuing concern during the last half of 1967. Again, the expectation that monetary restraint would result in markedly higher interest rates caused some members of the Committee to caution against a policy change. It was argued by some that higher interest rates in this country would cause a capital outflow from the United Kingdom, with corresponding pressure on the British international reserve position. 


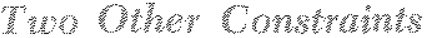

There are two constraints on monetary management which have been of constant concern for many years. One is a knowledge constraint and the other is an orderly money market constraint. Both of these constraints were present in the last half of 1967.

The knowledge constraint refers to a lack of knowledge of the precise state of the economy and of the specific impact on economic activity resulting from a change in monetary policy. Since economic data are reported with a considerable time lag, are frequently revised, and are subject to random forces, it is diffcult to recognize a turning point in economic activity until much time has lapsed. Moreover, the scientific underpinnings of monetary management are still very inadequate. There are major debates over the channels of monetary influence on economic activity, as well as debates over the relative strengths of different policy prescriptions.

As a result, in the early summer of last year there was disagreement in the Committee over the precise direction in which economic activity was moving. Then, when agreement was reached that inflation was prevalent, lack of precise knowledge led to cautious probing; that is, small changes in policy and in its implementation.

The second constraint is the desire for preventing disorderly money market conditions. Such conditions are characterized by a movement in prices of government securities, either up or down, which tend to be self-aggravating. Expectations of market participants are cited as causes of such price movements. There was little need to be concemed over this constraint last year, but it was cited in the last directive of the year which marked a change in emphasis toward monetary restraint. The proviso clause in that directive allowed for modification in open market operations to "moderate any apparently significant devitions of bank credit from current expectations or any unusual liquidity pressures."

\section{Results of Constraints}

The result of constraining monetary actions during most of the last half of 1967 was continuation of very expansionary monetary policy during the period of emerging inflation. Our interpretation of these events is that the factor underlying each constraint was a concern over interest rates rising too high. There appears to have been concem that interest rates should not rise sharply during even keel periods, that market interest rates above ceiling rates would cause disintermediation, that fiscal restraint was needed to avoid a marked rise in interest rates, and that a marked rise in this country's interest rates could further weaken the position of the pound sterling.

In retrospect, the imposition of these constraints on monetary management in some instances was not necessary, in other instances was not successful, and in the longer run was self-defeating. Interest rates were markedly higher in late 1967 than in the early fall, reflecting, in part, the stimulus given to economic activity during early 1967 by expansionary monetary actions. Nevertheless, the Treasury financings were successful, and substantial disintermediation did not occur. Despite efforts to dampen the upward trend in this country's interest rates, the United Kingdom devalued its monetary unit.

\section{CONCLUSIONS}

In the early 1960's the term "fine tuning" was developed with reference to economic stabilization actions. It was believed that the science of economics had progressed to the point where carefully designed adjustments in fiscal actions and monetary management could keep the economy moving over time in such a manner as to be consistent with its over-all economic goals. In this process of "fine-tuning," fiscal policy was usually assumed to play the major role, with monetary management assigned a subsidiary role.

The record of stabilization actions during the last half of 1967 indicates that the potential for fine tuning was not achieved. In theory, both fiscal actions and monetary management have the potential for readily being reversed when there are major changes in economic activity; but the achievement of needed economic restraint through either fiscal actions or monetary management was not realized until late in 1967. There was no conflict during the period between domestic and balance of payments goals because economic restraint was consistent with the achievement of both.

Stabilization authorities recognized the need for policy changes during the period. The President's budget message in early 1967 called for a 6 per cent surtax on incomes as a means of combating anticipated inflation later in the year. A 10 per cent surtax was recommended in August. Despite the recognition of serious inflationary pressures at that time by most experts, the tax proposals were not adopted by Congress. On the other hand, prominent members of Congress called for reductions in Government expenditures along with a hike in taxes, but such reductions were not forthcoming. This impasse demonstrates that the potential for fine tuning by fiscal 
actions is very difficult to achieve in our present environment.

According to the discussions presented in its policy record, the desirability of restraint was recognized by members of the Federal Open Market Committee in early fall. However, several constraints on adoption of a restrictive monetary policy were invoked by a majority of the Committee. Thus, the FOMC chose not to exercise monetary management's potential for fine tuming during a period when monetary restraint was appropriate.

The economy paid a price as the result of delaying a move toward a more restrictive stabilization policy. Inflationary pressure increased greatly late in the year and has continued well into 1968. There was a worsening in the U.S. balance of payments position and an accompanying gold problem. By attempting to hold back interest rate increases, the Federal Reserve System both validated and stimulated demands for credit by businesses and the Federal government. Consequently, such monetary aggregates as the monetary base, bank credit, and the money stock rose rapidly up to almost the year's end. The rapid monetary expansion contributed further to inflationary pressures.
Several lessons for economists, analysts, and policy makers also are available from the stabilization experience in the second half of 1967. First, appropriate fiscal action during a period of needed restraint seems to be at times most difficult to achieve. Second, delaying the implementation of monetary restraint in order to realize intermediate goals or objectives involves a cost to the economy in terms of price stability. Finally, the fact that rapid increases in interest rates during 1967 did not lead to appreciable financial disintermediation, or did not significantly interfere with Treasury financing activities, suggests that the threshold for such developments might have been underestimated.

The developments in 1967 carry important implications for the theory of economic stabilization policy. Stabilization theory generally has ignored, up to now, the problems related to adopting and implementing a policy change, particularly a move toward restraint. Until these two problems are solved, the following question should be kept in mind: What changes within our present economic, political, and social environment are necessary in order to carry out a rational economic stabilization policy?

LeONALL C. ANDERSEN

Michael O. Rigg

This article is available as reprint series No. 28.

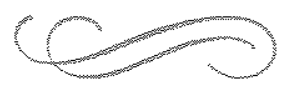

